\title{
Problems of learning Russian as a foreign language in a distance format at the pre-university stage
}

\author{
Maria Vladimirovna Alimova ${ }^{1 *}$, Daria Grigorievna Gutorova ${ }^{2}$, Tatyana Viktorovna \\ Kapshukova ${ }^{2}$, Ekaterina Stanislavovna Kozlovskaya ${ }^{1}$, and Ivanna Ivanovna Prokopova² \\ ${ }^{1}$ RUDN University, Russian Language Institute, Moscow, Russia \\ ${ }^{2}$ Plekhanov Russian University of Economics, Department of Russian Language and Culture of \\ Speech, Moscow, Russia
}

\begin{abstract}
In the 2020/2021 academic year, due to objective circumstances caused by the COVID-19 pandemic, Russian universities were forced to organize the admission of foreign citizens to preparatory departments exclusively in a distance format. This academic year turned out to be experimental and opened up many opportunities for both students and teachers. At the same time, taking into account the accumulated training experience, it can be concluded that when using an exclusively distance learning format, both advantages and significant disadvantages were identified, which, in turn, became a prerequisite for conducting the study. The purpose of this article is to identify and analyze in detail the main disadvantages of teaching types of speech activities in the online format and using remote learning platforms. The authors, as practicing teachers of Russian as a foreign language, directly faced all the problems considered in the article, and they observed the same difficulties among their colleagues. In this regard, the main methods for carrying out the work were methods characteristic of empirical research, first of all, observation, classification of results and generalization. The novelty of the research lies in the fact that for the first time an attempt was made to analyze the problems related to different areas of the organization and functioning of educational activities that arise in the distance learning process at the pre-university stage. This determines both theoretical and practical significance of the work carried out. As a result, the authors managed to summarize and systematize the disparate difficulties, which in the future may become the basis for finding systemic solutions to the identified problems.
\end{abstract}

Keywords: distance study, problem-focused research, pre-university education, Russian as a foreign language

\section{Introduction}

\footnotetext{
*Corresponding author: alimova mv@pfur.ru
} 
Before the pandemic caused by COVID-19, the question of the need to use distance learning format in universities remained controversial: scholars, methodologists and direct participants in the educational process - teachers and students - spoke about both advantages and disadvantages of this form of education [1-6].

In the 2020/2021 academic year, many students from abroad were unable to come to foreign universities, including those in Russia. For this reason, the use of distance learning has ceased to be "an opportunity, but became a necessity" [7]. For the first time in the practice of Russian universities, classes at the pre-university stage of training were conducted entirely in a distance format outside the language environment.

Shchukin considers the language environment as "a historically formed association of people based on a common language and culture and living in a certain territory" [8]. The presence of a natural language environment in the lessons of RFL is one of the factors contributing to the effective development of communicative competence among students studying Russian.

The specifics of learning outside the language environment during the COVID-19 period have changed a lot and acquired new characteristics. Based on the results of the academic year, we can say that adaptation of the full-time course in Russian as a foreign language, the effectiveness of which has been confirmed by many years of practice of its use, was associated with a number of technical, methodological, psychological and linguodidactic difficulties.

\section{$2 \quad$ Methods}

The study used theoretical, empirical and general logical methods such as analysis, synthesis, generalization, observation, description and comparison, as well as conversations and discussions.

\section{$3 \quad$ Results}

As a result of the study, the following problems were identified in various areas related to educational activities in a distance format.

Table 1. Problematic areas of distance learning at the pre-university stage.

\begin{tabular}{|c|c|}
\hline Problematic area & Cluster of identified problems \\
\hline Technical problems & $\begin{array}{l}\text { - insufficient provision of technical means; } \\
\text { - lack of flexible interactive online environment; } \\
\text { - shortage of academic hours; } \\
\text { - Internet signal interruptions; } \\
\text { - the use of additional technical means by students when } \\
\text { passing exams. }\end{array}$ \\
\hline Methodological problems & $\begin{array}{l}\text { - the problem of adapting the curriculum to electronic format; } \\
\text { - the problem of teaching writing and written speech; } \\
\text { - the problem of monitoring the learning process and assessing } \\
\text { learning outcomes. }\end{array}$ \\
\hline $\begin{array}{ll}\text { Psychological } & \text { and } \\
\text { pedagogical problems } & \end{array}$ & $\begin{array}{l}\text { - psychological discomfort during the use of technical teaching } \\
\text { aids; } \\
\text { - loss of focus and concentration during distance learning; } \\
\text { - lack of emotional and energetic contact of students with the } \\
\text { teacher and with each other. } \\
\text { - difficulties in identifying the individual characteristics of } \\
\text { students. }\end{array}$ \\
\hline
\end{tabular}




\section{Discussion}

Let us consider in more detail the cluster of problems identified in each of the above areas that make up the distance learning process.

\subsection{Technical problems}

One of the main sets of difficulties in teaching students of preparatory departments in a distance format are technical problems.

During the urgent transfer of classes to a distance learning format, all universities faced the problem of providing both teachers and students with technical means (computers, tablets and other means of communication). The problem of the lack of a developed information structure in universities, a small number of administrative personnel providing IT assistance to all participants in the educational process, still indicate that there are certain gaps in the implementation of distance learning.

Over the past academic year, all teachers mastered the theoretical basis for working with technical means, but we cannot talk about the effective use of the whole variety of educational and methodological materials to build the correct trajectory of online classes. Most preparatory departments use LMS platforms that host courses in Russian and other subjects, however, they do not have a flexible interactive online environment that allows students to replace face-to-face studies.

The academic year held remotely showed that the number of hours allocated for mastering the entire curriculum at the preparatory department is insufficient for full-fledged mastery of the Russian language at the B1 level. Constant presence in front of the monitor screen is viewed negatively by all participants in the educational process. Overall fatigue, trouble seeing clearly, and the lack of habitual human contact cause a drop of interest in online classes and less effective use of the allotted time. In addition, the problems of an unstable Internet signal often lead to disruption of classes.

A separate issue is the process of organizing control measures, which has already been considered [9], but has not lost its relevance. In the 2020/2021 academic year, all students of the preparatory departments had to take examination sessions remotely. Even despite careful preparation of examination assignments appropriate to this format, the use of video during control events, the online format cannot guarantee that students independently pass the exam and do not resort to pre-prepared materials.

\subsection{Methodological problems}

Let us list the methodological problems that the participants of the educational process encountered in the process of teaching RFL at the pre-university stage in a distance format.

The problem of adapting the curriculum to the electronic format. Basically, most textbooks have a PDF version, the use of which significantly limits the methodological capabilities of the teacher. Distance learning requires the use of not only the electronic version of the textbook, but also a whole range of multimedia materials that form an electronic educational environment. Thus, on the one hand, it is not enough just to use the PDF version of the textbook, because it needs to be adapted to the electronic format, on the other hand, it is not always that available software tools can adapt paper-based training materials. As a result, the teacher is forced to spend a tremendous amount of effort, time and energy on preparing through an online lesson, on the selection and systematization of 
multimedia material. Pashkovskaya in her article on distance learning, asks a reasonable question: "If ICT are designed to save and economize the teacher's efforts and time, then why has the amount of time and effort spent on preparing for an online lesson and checking homework increased several times?" [10].

The problem of teaching writing and written speech. The issue of learning writing at the initial stage in a distance format is very acute. As rightly noted by Strelchuk, it is impossible to fully master written speech without mastering the skills of graphic writing, because when using only the keyboard, "the brain does not create cognitive memory maps, since the letters typed on the keyboard are not registered in consciousness" [11]. RFL teachers send students handwriting manuals, use a graphic tablet, yet the distance format does not allow students to see the teacher's movements when writing letters and words, and the teacher cannot follow in the lesson how students write letters and words on the other side of the screen.

Here we come to another methodological problem.

The problem of monitoring the learning process and assessing learning outcomes. The distance learning format requires implementation and conduct of high-quality proctoring both during the final exam and during the academic year at the time of intermediate control [12]. Without proctoring, it is impossible to obtain objective assessment of the learning outcomes at the preparatory department, however, speaking is the only linguistic aspect that can be assessed more objectively, yet, here, too, students found ways to resort to the help of third parties and employ auxiliary materials when answering. It is possible to solve this problem not by tightening the observation and control procedure, but by changing the approach to assessing learning outcomes by developing a new knowledge assessment system for a distance learning format, but this will require changes to the student knowledge control system in universities.

\subsection{Psychological and pedagogical problems}

A number of psychological and pedagogical problems arising in distance learning should also be noted.

Firstly, these are the difficulties associated with the technical side of distance learning: often due to an insufficient mastery of computer and software products, as well as due to the almost inevitable technical problems that arise during the educational process across the computer monitor, psychological discomfort appears.

Secondly, when studying via Internet platforms, students are often distracted by external factors, which slow down the pace of the lesson, and this also causes some discomfort for all participants in the educational process.

Another factor in the emergence of psychological and pedagogical problems is the lack of emotional and energetic contact of students with the teacher and with each other. This complicates the process of transferring sociocultural and worldview experience, reduces the cognitive and communicative capabilities of students and teachers, weakens educational motivation, and also leads to escalatory decrease in motivation based on the absence of the need to use speech experience in real life [13].

Of particular note is such a psychological and pedagogical problem as difficulty in determining the individual characteristics of students: "The educational material for distance learning is designed, as you know, rather for transfer of information to a certain "average learner", but not for personal interaction, and addresses him/her as an object of the information process" [14]. 


\section{Conclusion}

Thus, for effective teaching Russian as a foreign language in a distance format, it is necessary to solve problems of technical, methodological, psychological and pedagogical nature. In a distance format, students stay much longer at the stage of mechanical translation of phrases from their own language into Russian. Students studying the language remotely form understanding that the Russian language is a means of communication necessary for studying at a Russian university much later than students studying full-time in a linguistic environment. In turn, this can further provoke problems with speech and socio-cultural [15] adaptation among students who come to receive higher education at Russian universities in person after completing the pre-university stage of distance learning.

However, the range of distance learning problems is much wider than those identified in the study. In this regard, this issue requires further comprehensive and interdisciplinary study in order to find complex, systemic solutions.

\section{References}

1. M.M.S. de Oliveira, A.S.T. Penedo, V.S.Pereira, Dialogia, 29, 139-152 (2018)

2. R. Fojtik, Int J Inf Comm Tech Edu, 7(1), 14-23 (2018). https://doi.org/10.2478/ijicte-2018-0002

3. V.P. Mahlangu, The Good, the Bad, and the Ugly of Distance Learning in Higher Education, in Trends in E-learning, Mahmut Sinecen, IntechOpen (2018). https://doi.org/10.5772/intechopen.75702

4. L. Zormanova, The Advantages and Disadvantages of Distance Learning at University through the Eyes of Adult Students Using this Form of Study (2019). Accessed on: October 9, 2022. [Online]. Available: https://www.researchgate.net/publication/330467460_The_Advantages_and_Disadvant ages_of_Distance_Learning_at_University_through_the_Eyes_of_Adult_Students_Usi ng_this_Form_of_Study

5. T. Öçal, M. Halmatov, S. Ata, Educ Inf Technol (2021). https://doi.org/10.1007/s10639-021-10551-x

6. Ch. Foo, B. Cheung, K. Chu, BMC Med Edu, 21, 141 (2021)

7. Sh. Dhawan, J Edu Tech Sys, 49(1), 5-22 (2020). doi:10.1177/0047239520934018

8. E.G. Azimov, A.N. Shchukin, Novyi slovar metodologicheskikh terminov i ponyatii, Novyi slovar metodologicheskikh terminov i ponyatii (teoriya i praktika prepodavaniya yazykov) [A new dictionary of methodological terms and notions, A new dictionary of methodological terms and notions (theory and practice of teaching languages)] (IKAR publishing house, Moscow, 2009)

9. M.V. Alimova, D.G. Gutorova, I.I. Prokopova, Osobennosti organizatsii distantsionnoi obrazovatelnoi sredy dlya prepodavaniya russkogo yazyka kak inostrannogo $i$ sotsiokulturnoi adaptatsii inostrannykh studentov $v$ novykh realiyakh [Features of organization of distance learning environment for teaching Russian as a foreign language and socio-cultural adaptation of foreign students in the new reality], in Collection of abstracts of the international conference on advanced learning 
technologies, 124-127, EdCrunch Tomsk 2020 (Tomsk State University Publishing House, Tomsk, 2020)

10. S.S. Pashkovskaya, Rus Stud, 19(1), 85-101 (2021).

https://doi.org/10.22363/2618-8163-2021-19-1-85-10

11. E.N. Strelchuk, Rus Stud, 19(1), 102-115 (2021).

https://doi.org/10.22363/2618-8163-2021-19-1-102-115

12. G. Swan, J Learn Design, 10(1), 20-30 (2017)

13. P. Fidalgo, J. Thormann, O. Kulyk, J.A. Lencastre, Int J Edu Tech Higher Edu, 17, 18 (2020)

14. N.V. Marakhovskaya, A.I. Pilipenko, Problemy distantsionnogo obucheniya. Aspekt psikhologicheskikh i kognitivnykh barerov [Distance learning problems. Aspect of psychological and cognitive barriers] (BSTU publishing house, Bryansk, 2001)

15. M. Alimova, D. Gutorova, I. Prokopova, Osobennosti vnedreniya i perspektivy razvitiya distantsionnogo obucheniya russkomu yazyku kak inostrannomu (RFL) na dovuzovskom fakultete [Implementation Features and Development Prospects in Distance Learning of Russian as a Foreign Language (RFL) at Pre-University Faculty], in Communication Trends in the Post-Literacy Era: Polylingualism, Multimodality and Multiculturalism As Preconditions for New Creativity, 72 -89 (Ural University Press, 2020) 